\title{
Article/Artigo
}

\section{Extended-spectrum $\beta$-lactamase-producing Salmonella enterica serovar Oranienburg (CTX-M-2 group) in a pediatric hospital in Tucumán, Argentina}

\author{
Salmonella enterica serovar Oranienburg produtora de $\beta$-lactamase de espectro extendido \\ (grupo CTX-M-2) em um hospital pediátrico de Tucumán, Argentina
}

María Angela Jure ${ }^{1}$, Olga Aulet ${ }^{1}$, Ana Trejo ${ }^{2}$ and Marta Castillo ${ }^{1}$

\begin{abstract}
Introduction: Salmonella sp infections have been reported over recent years in hospitals in Argentina and other countries due to multiresistant strains. The aim of this study was to characterize the extended-spectrum $\beta$-lactamases in third-generation cephalosporin-resistant strains of Salmonella enterica serovar Oranienburg. Methods: We studied 60 strains isolated from children with gastroenteritis and/or extraintestinal complications. The antibiotic susceptibility patterns of the isolates were analyzed and the $\beta$-lactamases were characterized using phenotyping and genotyping methods. Results: All the strains were resistant to ampicillin, cefotaxime, cefepime and aztreonam and partially susceptible to ceftazidime, thus corresponding well with the resistance phenotype conferred by CTX-M-type $\beta$-lactamases. An isoelectric point enzyme ( $\mathrm{pI}=7.9$ ) was detected in all of the strains, and this was confirmed by PCR as a member of the CTX-M-2 group. Conclusions: This is the first report of Salmonella enterica serovar Oranienburg producing $\beta$-lactamases of the CTX-M- 2 group in a pediatric hospital in Tucumán, Argentina.
\end{abstract}

Key-words: Salmonella enterica serovar Oranienburg. Extended Spectrum $\beta$-lactamases.

\section{RESUMO}

Introdução: Em recentes anos foram informadas infecções por Salmonella sp em hospitais da Argentina e outros países devido as cepas multiresistentes. $\mathrm{O}$ objetivo deste estudo era caracterizar as $\beta$-lactamasas de espectro extendido em cepas de Salmonella enterica serovar Oranienburg resistentes às cefalosporinas de terceira geração. Métodos: Nós estudamos 60 cepas obtidas de pacientes com gastroenterites e com complicações extraintestinais. Os padrões de susceptibilidade antibiotica foram estudados em os isolamentos, as $\beta$-lactamasas foram caracterizadas por métodos fenotípicos e genotípicos. Resultados: Todas as cepas eram resistentes a ampicillin, cefotaxime, cefepime e aztreonam e parcialmente suscetível a ceftazidime que corresponde bem com o fenótipo de resistência conferido por as $\beta$-lactamasas tipo CTX-M. Na totalidade das cepas, se detectou uma enzima de ponto isoelétrico (pI) 7,9, confirmada por PCR como pertencente ao grupo CTX-M2. Conclusões: Este é o primeiro reporte de Salmonella enterica serovar Oranienburg produtora de $\beta$-lactamasa grupo CTX-M2 em um hospital pediátrico de Tucuman, Argentina.

Palavras-chaves: Salmonella enterica serovariedade Oranienburg. $\beta$-lactamasas de espectro extendido.

1. Instituto de Microbiología "Dr. Luis C Verna”. Facultat de Bioquímica, Química, Farmacia y Biotecnología. Universidad Nacional de Tucumán. San Miguel de Tucumán, Argentina. 2. Laboratorio de Bacteriología, Hospital del Niño Jesús. San Miguel de Tucumán, Argentina.

Address to: Dr. Marta Cecilia de Castillo. Av. Juan B. Justo 1192, San Miguel de Tucumán, Tucumán, 4000, Argentina.

Phone: 540381 424-7752 int 7013/0381 421-7450

e-mail: mecastillo@fbqf.unt.edu.ar; majure@fbqf.unt.edu.ar

Received in 22/09/2009

Accepted in 05/03/2010

\section{INTRODUCTION}

Nosocomial non-typhoid Salmonella infections have been reported over recent years in many geographic areas, including countries with high public health standards. Although Salmonella sp are not typical members of hospital microflora, several outbreaks due to multiresistant isolates have been reported in hospitals from Argentina, as well as in other countries ${ }^{1,2}$. Although antibiotic therapy is not usually recommended for treating patients with Salmonella gastroenteritis, invasive complications such as meningitis, sepsis and bacteremia require it ${ }^{3}$.

From 1969 to 1985, the most prevalent Salmonella serovar in hospitals in different cities in Argentina was Salmonella serovar Typhimurium, followed by serovar Oranienburg. Salmonella enterica serovar Enteritidis emerged in 1986 and has been mainly involved in food-poisoning outbreaks ${ }^{4}$.

Salmonella strains resistant to extendedspectrum cephalosporins (ESCs) have been reported since the late 1980s and the number of strain types has been increasing ever since ${ }^{5}$. The major resistance mechanism identified involved an extended-spectrum $\beta$-lactamase (ESBL) that was able to hydrolyze monobactams and oxyimino cephalosporins (such as cefotaxime and ceftazidime) but not cephamycins ${ }^{6,7}$.

CTX-M $\beta$-lactamases (cefotaximases) are a relatively novel family of plasmid-mediated ESC and have been classified as Ambler class A. These enzymes generally possess higher levels of hydrolytic activity against cefotaxime than against ceftazidime, and are inhibited by clavulanic acid, sulbactam and tazobactam. They also provided resistance to cefepime. On the basis of their amino acid sequences, CTX-M enzymes have been classified into five mayor phylogenetic branches (groups 1, 2, 8, 9 and 25) ${ }^{7}$. This group of enzymes is one of the most frequently encountered ESBL types in Salmonella sp ${ }^{5}$. 
Resistance to ESC was detected first in Salmonella serovar Typhimurium and later in Salmonella serovars Infantis and Agona ${ }^{4}$.

Only a few cases of major outbreaks associated with serovar Oranienburg have been reported over the last 35 years, but this serovar has been consistently observed in isolated cases of food poisoning. Thus, it is placed among the 15 most frequently reported Salmonella serovars from human sources, according to the Centers for Disease Control and Prevention, Atlanta, GA, USA (CDC) ${ }^{8}$.

The aims of this study were to serotype and biotype ESCresistant Salmonella sp, investigate extended-spectrum $\beta$-lactamases in these strains and characterize these enzymes phenotypically and genotypically.

\section{METHODS}

Between June 2005 and May 2006, we studied 60 Salmonella sp strains isolated from children hospitalized in five rooms at the Niño Jesús Hospital. Fifty isolates were of gastrointestinal origin and ten were extraintestinal (blood, puncture material and urine). The children's ages ranged from one to thirty-six months.

\section{Serotyping}

Serotyping of Salmonella $s p$ isolates was carried out by means of slide agglutination with commercial antisera (Sanofi Pasteur Diagnostics, Paris, France), using the Kauffmann-White scheme?

\section{Antimicrobial susceptibility testing}

Antibiotic susceptibility was tested on the population of Salmonella enterica serovar Oranienburg. The antibiotic susceptibility test was performed using the disk diffusion method (Kirby Bauer). The antibiotics tested were: ampicillin, cephalothin, cefotaxime, cefepime, ceftazidime, aztreonam, imipenem, ciprofloxacin, trimethoprim plus sulfamethoxazole, gentamicin, amikacin, chloramphenicol, amoxicillin plus clavulanic acid and piperacillin plus tazobactam. Interpretation of inhibition zones was performed in accordance with the Clinical Standards Institute criteria (CLSI), and quality control was performed using the Escherichia coli ATCC 25922, E. coli ATCC 35218 and Klebsiella pneumoniae ATCC 700603 reference strains. Screening for ESBL was performed in accordance with CLSI recommendations using the double-disk synergy test with amoxicillin-clavulanic acid versus cefotaxime and ceftazidime disks with distances of $15 \mathrm{~mm}$ from edge to edge. Cefotaxime disks versus cefotaxime-clavulanic and ceftazidime disks versus ceftazidimeclavulanic were used to confirm ESBL production ${ }^{10}$.

\section{Preparation of crude extracts of $\beta$-lactamase and isoelectric focusing}

The isoelectric focusing procedure was performed as described previously ${ }^{11}$. Bacteria were harvested from a 20 -h brain heart infusion broth culture by centrifugation, and the pellet was resuspended in $1 \mathrm{ml}$ of phosphate buffer $(0.05 \mathrm{M} \mathrm{pH} 7)$. The enzymes were released by means of two cycles of freezing $\left(-70^{\circ} \mathrm{C}\right)$ and thawing (room temperature) and by sonication for $5 \mathrm{~min}$ in a sonicator in ice-cold water. Isoelectric focusing was performed on an ampholine polyacrylamide gel ( $\mathrm{pH} 3.0$ to 10.0; Pharmacia, Uppsala, Sweden). $\beta$-lactamase activity was detected using preparations of the chromogen nitrocefin from the standard strain K. pneumoniae 1803 (clinically isolated), which is known to harbor Per-2, and CTX-M2 was used as a standard.

\section{PCR amplification for bla ${ }_{\text {CTX-M2 }}$ group}

For amplification of complete structural genes highly related to the CTX-M2 enzyme ( bla $_{\text {CTX-M2 }}$, the following primers (Gibco BRL) were used: bla ${ }_{\text {CTX-M2 }}$ 5 'CGGAATTCATGATGACTCAGAGCATTCG3' (forward), 5' GCTCTAGATTATTGCATCAGAAACCGTG3' (reverse). The reactions were performed in a Biometra DNA thermal cycler (trio-thermoblock) in 50ul mixtures containing 2.5U of Taq polymerase (Promega, Madison, WI, USA) and $1 \mathrm{x}$ buffer consisting of $10 \mathrm{mM}$ Tris- $\mathrm{HCl}$ ( $\mathrm{pH} 8.3$ ), $1.5 \mathrm{mM} \mathrm{MgCl}_{2}, 50 \mathrm{mM} \mathrm{KCl}, 0.01 \mu \mathrm{g}$ of gelatin and each oligonucleotide at a concentration of 50 pmoles. Thirty-five cycles were performed for each reaction, with the following temperature profile for each cycle: $94^{\circ} \mathrm{C}$ for $1 \mathrm{~min}, 55^{\circ} \mathrm{C}$ for $1 \mathrm{~min}$, and $72^{\circ} \mathrm{C}$ for $1 \mathrm{~min}$. The gels were then stained with ethidium bromide and photographed under UV light ${ }^{12,13}$.

\section{RESULTS}

\section{Serotyping}

The 60 Salmonella $s p$ isolates were serotyped as Salmonella enteritidis serovar Oranienburg.

\section{Antimicrobial susceptibility testing}

Antimicrobial susceptibility was determined for all 60 ESBLproducing strains. All the isolates displayed coresistance to gentamicin and netilmicin.

The $\beta$-lactam susceptibility phenotype was determined for all the Salmonella ESBL - producing strains. These strains were resistant to ampicillin, cephalothin, cefoxitin, cefotaxime, cefepime, aztreonam and cefpodoxime. They appeared to be partially susceptible to ceftazidime, and were susceptible to imipenem and cefoxitin. The activity of piperacillin was partially restored by means of inhibitors such as tazobactam. The synergy between cefotaxime and clavulanic acid confirmed that an ESBL was produced (Figure 1). The higher levels of resistance to cefotaxime versus ceftazidime corresponded well with the resistance phenotype conferred by the CTX-M-type ESBLs in Salmonella spp. The strains

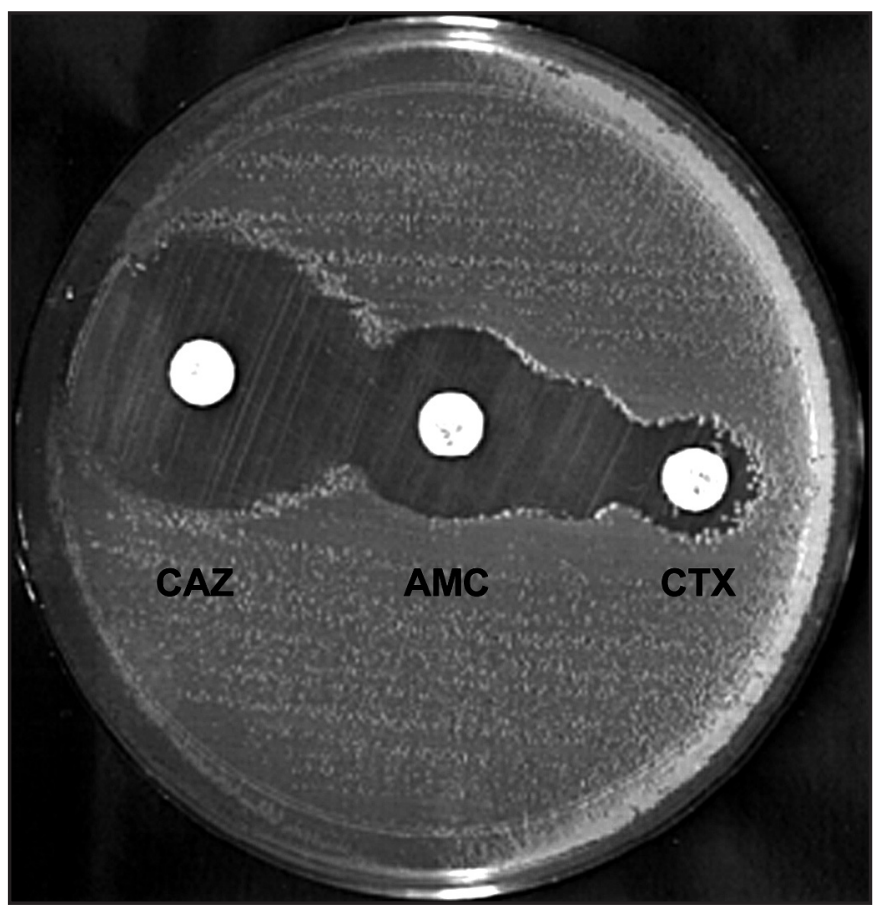

FIGURE 1- Double-disk synergy test for ESBL detection. 
were susceptible to ciprofloxacin, amikacin, trimethoprim plus sulfamethoxazole and chloramphenicol.

\section{Isoelectric focusing}

This revealed that a $\beta$-lactamase with isoelectric point of 7.9 was produced in all isolates, which confirmed that one of the CTX-M family might be responsible for the phenotype observed (Figure 2).

\section{PCR amplification for bla ${ }_{\mathrm{CTX}-\mathrm{M} 2}$ group genes}

A 896-bp amplicon was obtained when using primers directed against the bla $a_{\text {СтХ-м2 }}$ group genes in all Salmonella enterica serovar Oranienburg isolates (Figure 3).

The 60 Salmonella enterica serovar Oranienburg isolates were identical They presented a resistance phenotype conferred by the CTX-M-type ESBLs and a $\beta$-lactamase with isoelectric point of 7.9. All the isolates were positive for $b l a_{\text {СтХ-м2 }}$ group genes.

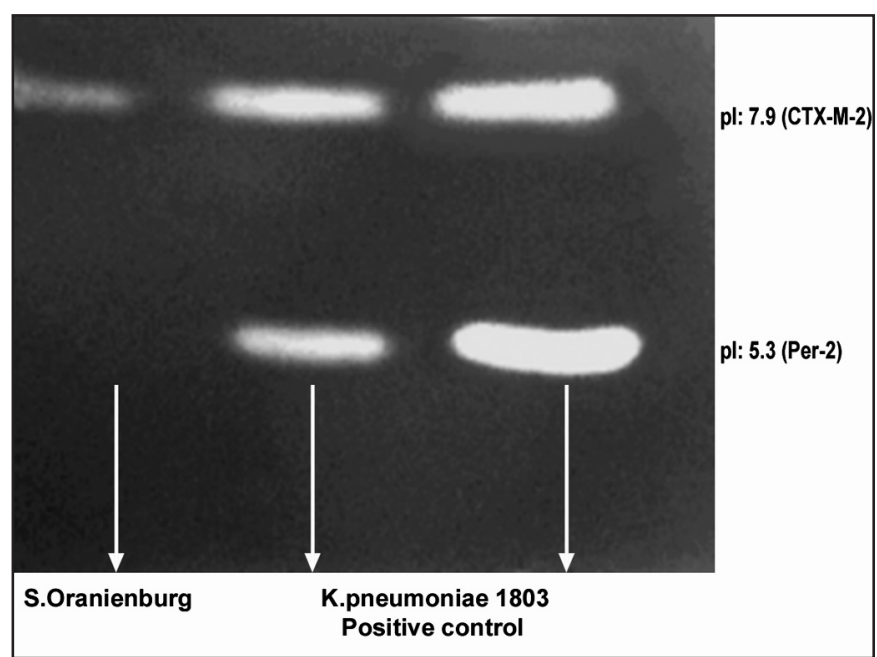

FIGURE 2 - Isoelectric focusing on polyacrylamide gel

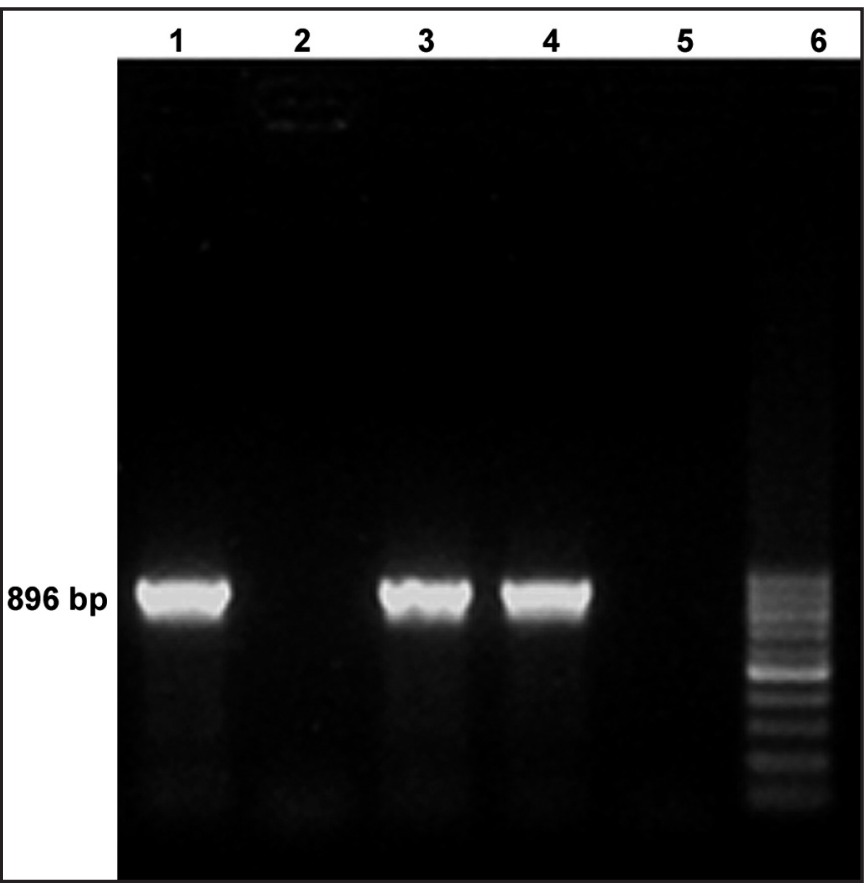

FIGURE 3 - Amplification products obtained using PCR on bla CTX-M-2 group genes, analyzed by means of agarose gel electrophoresis. Lane 1: 896bp fragment corresponding to blaCTX-M-2 groupgenes, positive control K.pneumoniae 1803; lane 2: negative control (E.coliATCC25.922); lanes 3 and 4: 896 bp fragmentcorresponding to bla CTX-M-2 group genes in Salmonella Oranienburg isolates; lane 5: negative control (reactant mixture without template); lane 6: lambda 100bp marker.

\section{DISCUSSION}

Salmonella enterica serovar Oranienburg is frequently isolated from children with gastroenteritis. This is the first time that extendedspectrum $\beta$-lactamases in strains isolated in our hospital have been characterized phenotypically and genotypically.

There have been scattered reports involving serovar Oranienburg from many parts of the world, including the Maldives ${ }^{14}$, Norway ${ }^{15}$ and the United States ${ }^{16}$.

The genus Salmonella is not commonly regarded as hospital flora and extended-spectrum- $\beta$-lactamase (ESBL) production with multiple antibiotic resistance is rarely associated with this organism. Constant antibiotic pressure can select multidrug resistance and ESBL-producing bacteria, thereby enabling their transmission among hospitalized patients ${ }^{17}$. In Argentina, CTX-M-2 emerged in August 1990 and appeared in a multiresistant strain of Salmonella typhimurium ${ }^{18}$. Several CTX-M-like enzymes from all over the world have been described. In 2004, Liebana et al reported CTX-M-15 that was characterized in 2002 from a pediatric patient infected with $S$. enterica serotype Infantis in Honduras ${ }^{19}$. The first cefotaximase-producing strain (CTX-M-3) was reported in a nonclinical S. enterica serovar Senftenberg in Japan in $2004^{20}$. Also in 2004, a nosocomial outbreak of pediatric gastroenteritis in Korea was caused by CTX-M-14-type ESBL-producing strains of S. enterica serovar London ${ }^{21}$. Bonnet, in 2004 reported S. enterica serovar Typhimurium strains harboring distinct CTX-M- $3^{7}$. A large outbreak of Salmonella gastroenteritis that involved 4,000 children in Latvia in 1990 was associated with a S. typhimurium strain producing CTXM- $\beta$-lactamases ${ }^{22}$. In Barcelona, Spain, CTX-M-9 was reported in S. enterica serovar Virchow ${ }^{23}$. In Ireland, CTX-M-15 and CTX-M-14 were reported ${ }^{24}$. Orman et al clearly showed that, in Argentina, the emergence of resistance to ESC in the genus Salmonella was due to acquisition of the $b l a_{\mathrm{CTX}-\mathrm{M} 2}$ genes ${ }^{4}$. Our results demonstrated the presence of CTX-M-2 group enzymes in our Salmonella enterica serovar Oranienburg strains. This event could be related to the widespread use of cefotaxime and ceftriaxone rather than ceftazidime in our hospitals, among other factors.

Several serovars of ESBL-producing Salmonella spp were reported: in Argentina due to Salmonella enterica serovar Infantis ${ }^{25}$, in Poland due to Salmonella enterica serovar Oranienburg ${ }^{26}$, in Russia due to Salmonella enterica serovar Typhimurium ${ }^{27}$ and in Honduras due to Salmonella enterica serovar Infantis ${ }^{19}$.

The $\beta$-lactam susceptibility phenotype was determined for all the Salmonella enterica serovar Oranienburg ESBL-producing strains. These strains were resistant to ampicillin, cefotaxime, cefepime and aztreonam. They appeared to be partially susceptible to ceftazidime and were susceptible to imipenem and cefoxitin. These results corresponded well with the resistance phenotype conferred by the CTX-M type ESBLs in Salmonella sp. These strains were susceptible to ciprofloxacin, amikacin, trimethoprim plus sulfamethoxazole and chloramphenicol. All the isolates displayed coresistance to gentamicin and netilmicin. Similar data were found by Yong et al, in a pediatric hospital in Korea ${ }^{22}$ and by Orman et al, in Argentina between 1993 and $1998^{4}$.

The isoelectric focusing made it possible to ascertain the $\mathrm{pI}$ of the proteins. Many ESBLs have the same pI, and therefore it is useful to compare it with the sensitivity phenotype, in order to gain knowledge 
about the ESBL type for subsequent analysis or molecular study. Our results demonstrated the presence of an enzyme with pI 7.9 coincident with Saka et al, in Cordoba, Argentina ${ }^{28}$.

The number of infected patients with ESBL-producing strains is increasing ${ }^{5}$. Asymptomatic carriers may be a source of dissemination of these microorganisms and are involved in their persistence and dissemination $^{29}$.

This is the first report of Salmonella enterica serovar Oranienburg producing the CTX-M-2 group in a pediatric hospital in Tucumán, Argentina. From our study, we consider that the implied transmission route in the five affected rooms was probably horizontal.

\section{CONFLICT OF INTEREST}

The authors declare that there is no conflict of interest.

\section{FINANCIAL SUPPORT}

This work was supported by Consejo de Investigaciones de la Universidad Nacional de Tucumán (CIUNT).

\section{REFERENCES}

1. Maiorini E, López EL, Morrow AL, Ramirez F, Procopio A, Furmanski S, et al. Multiply resistant nontyphoidal Salmonella gastroenteritis in children. Pediatr Infect Dis J 1993; 12:139-145.

2. Cordano AM, Virgilio R. Evolution of drug resistance in Salmonella panama isolates in Chile. Antimicrob Agents Chemother 1996; 40:336-341.

3. Merino L, Ruiz J, Alonso M, Vila J. Resistencia antimicrobiana y epidemiología molecular en cepas de Salmonella enterica serovar Enteritidis aisladas en las provincias de Chaco y Corrientes (Argentina). Comunicaciones científicas y tecnológicas. Universidad Nacional del Nordeste 2005; Resumen: M-020.

4. Orman B, Piñeiro S, Arduino S, Galas M, Melano R, Caffer I, et al. Evolution of Multiresistance in Nontyphoid Salmonella Serovars from 1984 to 1998 in Argentina. Antimicrob Agents Chemother 2002; 46: 3963-3970.

5. Bertrand S, Weill FX, Cloeckaert A, Vrints M, Mairiaux E, Praud K. Collard Clonal emergence of extended spectrum $\beta$-Lactamase (CTX-M-2) producing Salmonella enterica Serovar Virchow isolates with reduced susceptibilities to Ciprofloxacin among Poultry and humans in Belgium and France (2000 to 2003). J Clin Microbiol 2006; 44:2897-2903.

6. Miriagou V, Filip R, Coman G, Tzouvelekis L. Expanded-Spectrum Cephalosporin-Resistant Salmonella Strains in Romania. J Clin Microbiol 2002; 40: 4334-4336.

7. Bonnet R. Growing group of extended-spectrum $\beta$-lactamases the CTX-M enzymes. Antimicrob Agents Chemother 2004; 48: 1-14.

8. Olsen SJ, Bishop FW, Brenner TH, Roels T, Bean R, Tauxe V, et al. The changing epidemiology of Salmonella trends in serotypes isolated from humans in the United States, 1987-1997. J Infect Dis 2001; 183: 753-761.

9. Kauffman F. Serologic diagnosis of Salmonella species. Munksgaard, Copenhagen, Denmark, 1972

10. Clinical and Laboratory Standards Institute/NCCLS. Performance standards for antimicrobial susceptibility tests. M100-S16, sixteenth informational supplement, CLSI, Wayne, PA; 2006.
11. Matthew M, Harris AM. Identification of $\beta$-lactamases by analytical isoelectric focusing: correlation with bacterial taxonomy. J Gen Appl Microbiol 1976; 94 : 55-67.

12. Bauernfeind A, Stempliger I, Jungwirth R, Ernst S, Casellas JM. Sequences of $\beta$-lactamase genes encoding CTX-M-1 (MEN-1) and CTX-M-2 and relationship of their amino acid sequences with those of other $\beta$-lactamases. Antimicrob Agents Chemother 1996; 40:509-513.

13. Petroni A, Corso A, Melano R, Cacace ML, Bru AM, Rossi A, et al. Plasmidic Extended-Spectrum $\beta$-lactamases in Vibrio cholerae O1 El Tor Isolates in Argentina. Antimicrob Agents Chemother 2002; 46:1462-1468.

14. Aggarwal R, Chowdhuri R. Simultaneous isolation of Salmonella Stanley and Salmonella Oranienburg from an outbreak of food poisoning at Maldives island. Indian J Med Res 1983; 77: 602-604.

15. Gustavsen S, Breen O. Investigation of an outbreak of Salmonella Oranienburg infection in Norway, caused by contaminated black pepper. Am J Epidemiol 1984; 119: 806-812.

16. Helderg CW, Korlath JA, Aoust KE, White WL, Schell MR, Osterholm MT. A multistate outbreak of Salmonella Javiana and Salmonella Oranienburg infections due to consuption of contaminated cheese J Am Med Assoc 1992; 268: 3203-3207.

17. Rossi A, Tokumoto M, Couto A, Di Bella A, Alstchuler M, Gómez N, et al. Survey of the levels of antimicrobial resistance in Argentina WHONET program 1991-1994. Int J Antimicrob Agents 1985; 6: 103-110.

18. Rasmussen JW, Hoiby N. Cefotaximases (CTX-M-ases) an expanding family of extended-spectrum $\beta$-lactamases. Can J Microbiol 2004; 50: 137-165.

19. Liébana E, Batchelor M, Torres C, Briñas L, Lagos L, Abdalhamid B, et al. Pediatric Infection due to Multiresistant Salmonella enterica Serotype Infantis in Honduras. J Clin Microbiol 2004; 42: 4885-4888.

20. Ahmed AM, Nakano H, Shimamoto T. The first characterization of extendedspectrum $\beta$-lactamase producing Salmonella in Japan. J Antimicrob Chemother 2004; 57:283-284.

21. Yong D, Lim YS, Yum JH, Lee H, Lee K, Kim C, et al. Nosocomial Outbreak of Pediatric Gastroenteritis Caused by CTX-M-14-Type Extended-Spectrum $\beta$-Lactamase-Producing Strains of Salmonella enterica Serovar London. Pediatr Infect Dis J 2005; 43:3519-3521.

22. Tzouvelekis LS, Tzelepi E, Tassios PT, Legakis NJ. CTX-M-Type $\beta$-lactamases: an emerging group of extended-spectrum enzymes. Int J Antimicrob Agents 2000; 14:137-142.

23. Simarro E, Navarro F, Ruiz J, Miró E, Gómez J, Mirelis B. Salmonella enterica serovar Virchow with CTX-M-like $\beta$-lactamase in Spain. J Clin Microbiol 2000; 38: 4676-4678

24. Morris D, Whelan M, Corbett-Feeney G, Cormican M, Hawkey P, Li X D. First report of extended-spectrum $\beta$-lactamase-producing Salmonella enterica isolates in Ireland. Antimicrob Agents Chemother 2006; 50:1608-1609.

25. Di Conza J, Ayala P, Power M, Mollerach M, Gutkind G. Novel Class 1 integron (InS21) carrying bla CTX-M2 in Salmonella enterica serovar Infantis. Antimicrob Agents Chemother 2000; 46:2257-2261.

26. Gierczynski R, Szych J, Cieslik A, Rastawicki W, Jagielski M. The occurrence of the first two CTX-M-3 and TEM-1 producing isolates of Salmonella enterica serovar Oranienburg in Poland. Int J Antimicrob Agents 2003; 21: 497-499.

27. Edelstein M, Pimkin M, Dmitrachenko T, Semenov V, Kozlova N, Gladin D, et al. Multiple outbreaks of nosocomial salmonellosis in Russia and Belarus caused by a single clone of Salmonella enterica serovar Typhimurium producing an extendedspectrum $\beta$-lactamase. Antimicrob Agents Chemother 2004; 48: 2808-2815.

28. Saka HA, Egea M, Culasso C, Rollan R, Avaro A, Carvajal L. $\beta$-lactamasas de espectro extendido en Klebsiella pneumoniae aisladas en el Hospital de Niños de Córdoba, Argentina. Rev Argent Microbiol 2003; 35:1-7.

29. Wadula J, Von Gottberg A, Kilner D, Cohen C, Khoosal M, Keddy K, et al. Nosocomial Outbreak of Extended-Spectrum $\beta$-lactamase-Producing Salmonella Isangi in Pediatric Wards. Pediatr Infect Dis J 2006; 25:843-844. 